\title{
The effect of $Y$ on the microstructure and mechanical performance of an Mg-Al-Y casting alloy
}

\author{
K. Korgiopoulos* (D) and M. Pekguleryuz \\ McGill University, Materials Engineering, 3610 University St., Montreal, QC, Canada H3A 0C5 \\ *Corresponding author. Email: konstantinos.korgiopoulos@mail.mcgill.ca
}

(Received 29 September 2020; Revised 17 November 2020; Accepted 18 November 2020)

\begin{abstract}
Environmental gains of electric cars can be optimized with the use of lightweight and recyclable magnesium in the vehicle's structural components. Ductility improvement of low-density $\mathrm{Mg}-\mathrm{Al}$ alloys will extend their use in automotive body applications. The authors achieved 63\% ductility improvement in Mg-6wt\%Al with trace $\mathrm{Y}(1.5 \mathrm{ppm})$ due to the $\beta$-phase refinement and predicted that higher levels would not perform as well. As predicted, $0.3 \mathrm{wt} \%$ of $\mathrm{Y}$ addition investigated in this study led to lower mechanical performance and $\beta$-phase refinement than those obtained with trace additions. The tensile ductility and yield strength increased by $\sim 13 \%$ and $16 \%$, respectively, and the compression strain to fracture by $\sim 22 \%$. Scanning electron and optical microscopy, X-Rays diffraction, mechanical testing and thermodynamic calculations were used to investigate the effect of $0.3 \mathrm{wt} \% \mathrm{Y}$ on the microstructure of $\mathrm{Mg}-6 \mathrm{wt} \% \mathrm{Al}$. The matrix dissolution revealed the close association of the $\mathrm{Al}_{2} \mathrm{Y}$ and the $\beta-\mathrm{Mg}_{17} \mathrm{Al}_{12}$ phases.
\end{abstract}

Keywords: Magnesium; Mg-Al alloys; Matrix extraction; Tensile ductility; Compressive strain

\section{Introduction}

Future autonomous cars will rely on computer systems, sensors, and satellite navigation which require extensive electronics that increase the vehicle's weight (Gao et al., 2014). Due to their high strength-toweight-ratio, magnesium $(\mathrm{Mg})$ structural alloys are a viable solution for vehicle-weight reduction in future cars. Mg-6wt\%Al (Mg-6Al) casting alloys demonstrate the optimum level of strength and ductility for most automotive applications but further increase in their ductility will lead to their extended use in crashworthy car-body components (Friedrich \& Mordike, 2006). The $\mathrm{Mg}_{17} \mathrm{Al}_{12}$ precipitate, the main second phase, improves strength but reduces ductility (Friedrich \& Mordike, 2006; Nave et al., 2000).

Studies have shown that yttrium (Y) additions can improve the ductility of $\mathrm{Mg}$ - $\mathrm{Al}$ alloys (Su et al., 2010; Tahreen et al., 2016). When $\mathrm{Y}$ is in the solid solution of $\alpha$-Mg then it can improve its mechanical properties via: (1) decrease of the Stacking Fault Energy (SFE) activating the pyramidal $\langle\mathrm{c}+\mathrm{a}\rangle$ disclocations (Sandlöbes et al., 2012) or (2) forming long period stacking ordered (LPSO) phases when a transition metal is present (Kawamura \& Yamasaki, 2007). However, with Al present, the solubility of rare earths in $\alpha-\mathrm{Mg}$ is nil, instead brittle precipitates (Pourbahari et al., 2017; C. Wang et al., 2015; L. Wang et al., 2019) form. Researchers have observed that the modification of $\beta-\mathrm{Mg}_{17} \mathrm{Al}_{12}$ in $\mathrm{Mg}-\mathrm{Al}-\mathrm{Y}$ alloys is responsible for improved mechanical properties (Boby et al., 2013; Cai et al., 2018; Kashefi \& Mahmudi, 2012; S.-R. Wang et al., 2009). Previous work (Korgiopoulos \& Pekguleryuz, 2020) by the

\footnotetext{
(C) The Author(s), 2021. Published by Cambridge University Press. This is an Open Access article, distributed under the terms of the Creative Commons Attribution licence (http://creativecommons.org/licenses/by/4.0), which permits unrestricted re-use, distribution and reproduction, provided the original article is properly cited.
} 
authors has shown that the refinement of $\beta-\mathrm{Mg}_{17} \mathrm{Al}_{12}$ improves the ductility of $\mathrm{Mg}-6 \mathrm{Al}$ cast alloys at trace $\mathrm{Y}$ additions. This has been attributed to co-precipitation (at close temperatures) of the $\mathrm{Al}_{4} \mathrm{MgY}$ phase with the $\mathrm{Mg}_{17} \mathrm{~A}_{12}$ phase. Thermodynamics also predicted that the formation temperatures of the two phases deviate at higher $\mathrm{Y}$ levels leading to a loss in nucleant effectiveness.

\section{Objective}

The current work investigates the effect of $Y$ additions ( $0.3 \mathrm{wt} \%)$ to see if $\beta$-phase refinement and ductility improvement seen in trace levels of $\mathrm{Y}$ are also observed at higher $\mathrm{Y}$ levels and to elucidate the role of $\mathrm{Y}$ on the mechanical properties of $\mathrm{Mg}-6 \mathrm{Al}$ based alloys.

\section{Methods}

Mg-6Al-0.3Y (in wt\%) alloy was synthesized using commercial purity (99.98\%) $\mathrm{Mg}, 99.9 \%$ pure $\mathrm{Al}$ granules and $99.9 \%$ pure $\mathrm{Y}$ rods. The total mass of the alloying additions was 617 gr using $95 \%$ recovery factor for $\mathrm{Al}$ and $60 \%$ for $\mathrm{Y}$. The alloying additions were made at $720{ }^{\circ} \mathrm{C}$ in a graphite crucible under $\mathrm{CO}_{2} / \mathrm{SF}_{6}$ protective atmosphere. A graphite crucible was used because it is affordable, and it does not react with magnesium. The cleaning after casting is efficient and leaves no residuals that could possibly contaminate the subsequent castings. The molten alloy was then poured under protective atmosphere into a preheated $\left(400^{\circ} \mathrm{C}\right)$ steel mold to produce a flat plate. The actual composition (in wt\%) of the alloy according to inductively coupled plasma atomic-emission spectroscopy is: $6.26 \% \mathrm{Al}, 0.29 \% \mathrm{Y}, 0.02 \%$ impurities (Fe, Mn) with $\mathrm{Mg}$ as balance. A scanning electron microscope (SEM-Hitachi SU3500) with an energy dispersive X-ray spectroscopy (EDS) detector was used for microstructural investigation. The grain size of $\alpha-\mathrm{Mg}$ was measured with the intercept method using a Nikon-Epiphot 200 optical microscope after etching the samples with $4.2 \mathrm{gr}$ picric acid, $10 \mathrm{ml}$ acetic acid, $10 \mathrm{ml}$ distilled water and $70 \mathrm{ml}$ ethanol. The ImageJ software (Rasband, 2011) was used to measure the precipitates and the grain size. The crystallographic information was obtained by XRD (Bruker D8 Discovery X-Ray Diffractometer-Cu source) in the bulk sample and after matrix extraction by using $5 \%$ acetic acid. The mechanical properties were evaluated by tensile and compression testing (MTS 810) at room temperature with a strain rate of $0.001 \mathrm{~s}^{-1}$. Thermodynamic calculations (FactSage with FTlite database) (Bale et al., 2002) based on the CALPHAD method have been performed in equilibrium and non-equilibrium conditions (Scheil cooling).

\section{Results and discussion}

Mg-6Al-0.3Y alloy consists of partially divorced $\beta-\mathrm{Mg}_{17} \mathrm{Al}_{12}$, interdendritic $\mathrm{Y}$-enriched precipitates and the $\mathrm{Al}$ enriched $a-\mathrm{Mg}$ phase as determined by EDS (Fig. 1). $\mathrm{Y}$ is detected in $\mathrm{Mg}-\mathrm{Al}-\mathrm{Y}$ and $\mathrm{Mg}-\mathrm{Al}-\mathrm{Mn}-$ $\mathrm{Fe}-\mathrm{Y}$ precipitates. Both precipitates are closely associated with $\mathrm{Mg}_{17} \mathrm{Al}_{12}$ suggesting that they act as nucleation sites. The Y-enriched precipitates range from fine to coarse and present in three different morphologies, namely, spherical, square and plate-like, with the expectation that only the finer precipitates can act as refiners for the $\beta$ phase. Table 1 shows the composition of the $\beta$-phase and $\mathrm{Al}_{2} \mathrm{Y}$ as per the EDS analysis. No Y was detected in the $a$-Mg solid solution. There is close association (Figs 1 and 2 ) of the $\mathrm{Al}_{2} \mathrm{Y}$ precipitates with the $\mathrm{Mg}_{17} \mathrm{Al}_{12}$. Similar association has been observed before by the authors (Korgiopoulos \& Pekguleryuz, 2020) in Mg-6\%Al based alloys for lower Y additions. XRD detects (Fig. 3a) $\mathrm{Mg}$-Al solid solution and $\beta-\mathrm{Mg}_{17} \mathrm{Al}_{12}$ peaks in the bulk alloy. After the matrix extraction (Fig. 3b), the matrix disappears and the peaks for $\mathrm{Al}_{2} \mathrm{Y}$ and $\mathrm{Mg}_{17} \mathrm{Al}_{12}$ become stronger. The peak intensity of spectra $b$ is lower due to the low amount and small size (average size $\sim 10-50$ microns) of the extracted precipitates.

The $\mathrm{Mg}_{17} \mathrm{Al}_{12}$ (Table 2) in Mg-6Al-0.3Y is $25 \%$ finer than that in the binary Mg-6Al, but $41 \%$ coarser than the alloy with trace $\mathrm{Y}$ amount. Additionally, high $\mathrm{Y}$ addition forms even coarser $\left(\sim 87 \mu \mathrm{m}^{2}\right) \mathrm{Mg}$-Al$\mathrm{Mn}-\mathrm{Fe}-(\mathrm{Y})$ and $\mathrm{Mg}-\mathrm{Al}-\mathrm{Y}$ precipitates. The grain size of the cast $\mathrm{Mg}-6 \mathrm{Al}-0.3 \mathrm{Y}$ is also higher than the alloy 


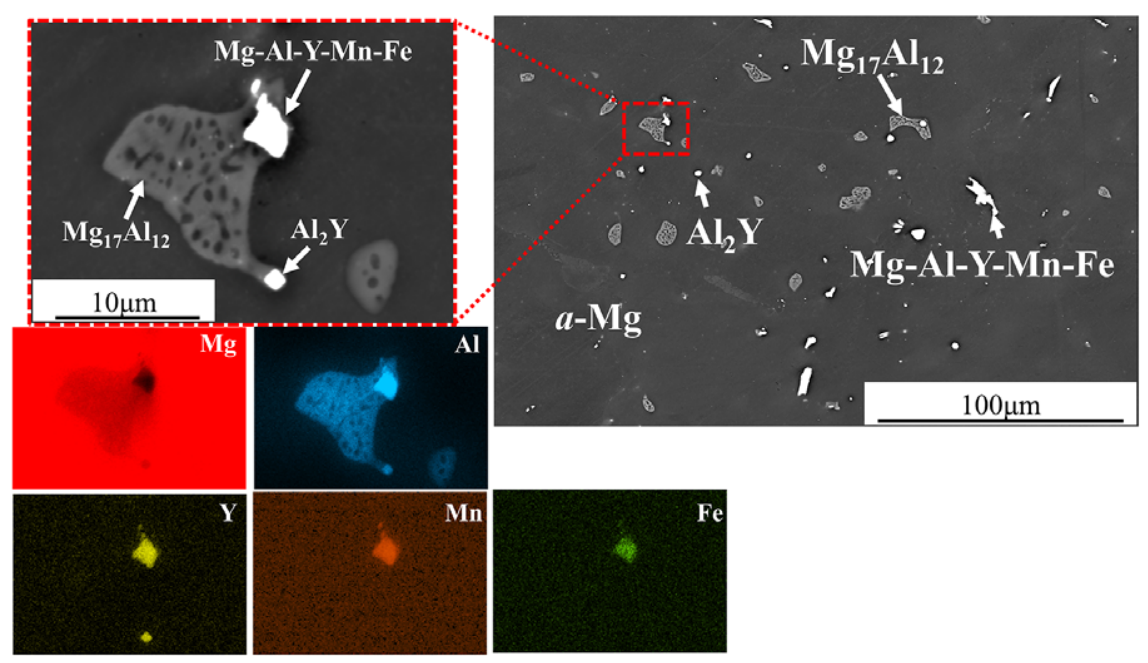

Figure 1. SEM/BSE as-cast microstructure of Mg-6Al-0.3Y and EDS maps. The red square shows the close associations of $Y$ enriched precipitates with $\mathrm{Mg}_{17} \mathrm{Al}_{12}$.

Table 1. EDS on the precipitates after matrix extraction

\begin{tabular}{lccr}
\hline Precipitate & $\mathrm{Mg}(\mathrm{at} \%)$ & $\mathrm{Al}(\mathrm{at} \%)$ & $\mathrm{Y}(\mathrm{at} \%)$ \\
\hline $\mathrm{Mg}_{17} \mathrm{Al}_{12}$ & $57.2 \pm 0.4$ & $42.8 \pm 0.4$ & - \\
\hline $\mathrm{Al}_{2} \mathrm{Y}$ & $2.3 \pm 1.2$ & $61.5 \pm 1.9$ & $36.2 \pm 0.7$ \\
\hline
\end{tabular}

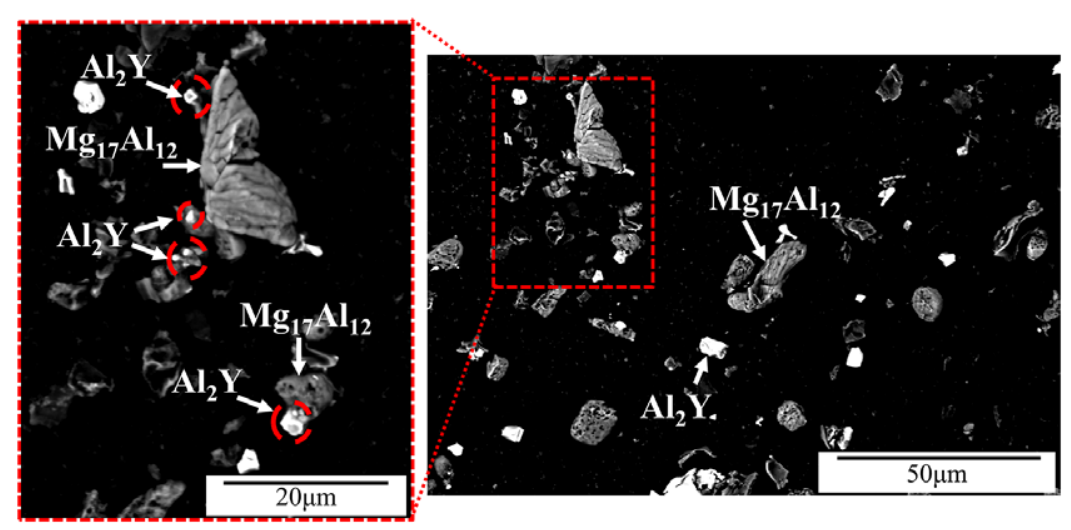

Figure 2. Mg-Al-0.3Y alloy after matrix extraction. The red circles show the $\mathrm{Al}_{2} \mathrm{Y}$ precipitates associated with the $\mathrm{Mg}_{17} \mathrm{Al}_{12} \mathrm{phase}$

with trace $\mathrm{Y}$ level and it is attributed to the coarsening of the $\mathrm{Al}_{2} \mathrm{Y}$ phase (Chang et al., 2013; Pan et al., 2008; Zou et al., 2005).

Mg-6Al-0.3Y has the highest tensile yield strength (YS) of the three alloys (Table 3). Compared to the $\mathrm{Mg}$-Al with trace $\mathrm{Y}$, the tensile ductility (\% El), ultimate tensile strength (UTS), and the compressive strength are lower (Tables 3 and 4). According to thermodynamic simulations conducted by the authors (Table 5), the solubility of $\mathrm{Y}$ in $\mathrm{Mg}-\mathrm{Al}-\mathrm{Y}$ is practically nil. Instead, $\mathrm{Y}$ forms precipitates (ordered intermetallics) with $\mathrm{Al}$ such as $\mathrm{Al}_{4} \mathrm{MgY}, \mathrm{Al}_{3} \mathrm{Y}$ and $\mathrm{Al}_{2} \mathrm{Y}$. In Mg-Al-0.3Y, $\mathrm{Al}_{2} \mathrm{Y}$ forms earlier (at higher temperature) than the $\beta$-phase (Table 5) and has time to coarsen losing its effectiveness as a nucleant of the $\beta$-phase and embrittling the alloy. 


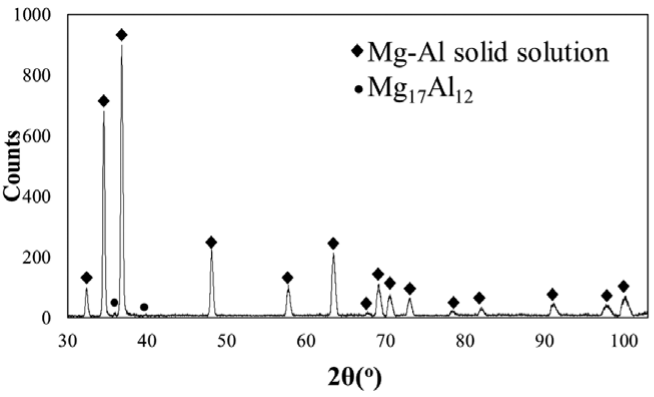

(a)

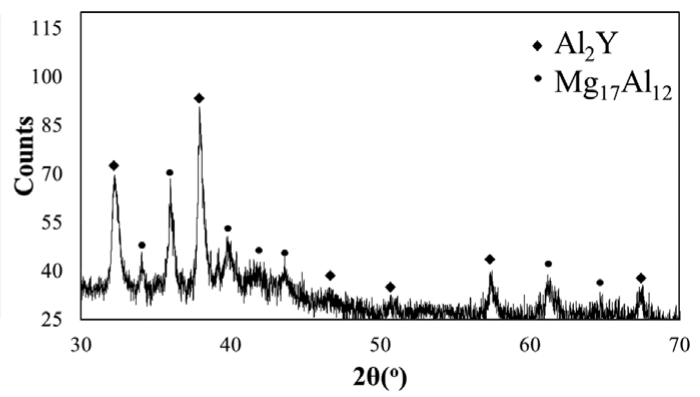

(b)

Figure 3. XRD results (a) Bulk alloy, (b) after matrix extraction.

Table 2. Precipitates size and $\alpha-M g$ grain size as measured with Image $\mathrm{J}$

\begin{tabular}{lccccc}
\hline Alloys & $\begin{array}{c}\mathrm{Mg}_{17} \mathrm{Al}_{12} \text { Size } \\
\left(\mu \mathrm{m}^{2}\right)\end{array}$ & $\begin{array}{c}\text { Mg-Al-Mn-Fe- }(\mathrm{Y}) \\
\text { Size }\left(\mu \mathrm{m}^{2}\right)^{*}\end{array}$ & $\begin{array}{c}\text { Mg-Al-Y Size } \\
\left(\mu \mathrm{m}^{2}\right)\end{array}$ & $\begin{array}{c}\alpha \text {-Mg Grain } \\
\text { Size }(\mu \mathrm{m})\end{array}$ & Reference \\
\hline Mg-6Al & $32 \pm 15$ & $1.56 \pm 0.06$ & - & $96 \pm 13$ & $\begin{array}{c}\text { (Korgiopoulos \& } \\
\text { Pekguleryuz, 2020) }\end{array}$ \\
\hline $\begin{array}{c}\text { Mg-6Al with } \\
\text { trace Y }\end{array}$ & $17 \pm 5$ & $1.41 \pm 0.20$ & - & $85 \pm 15$ & $\begin{array}{c}\text { (Korgiopoulos \& } \\
\text { Pekguleryuz, 2020) }\end{array}$ \\
\hline Mg-6Al-0.3Y & $24 \pm 6$ & $7 \pm 3$ & $14 \pm 10$ & $105 \pm 17$ & Current work \\
\hline
\end{tabular}

*Only precipitates in Mg-6Al-0.3Y alloy contain Y.

Table 3. Tensile properties of as cast samples at room temperature

\begin{tabular}{lccll}
\hline Alloy & UTS(MPa) & YS(MPa) & El (\%) & Reference \\
\hline Mg-6Al & $206 \pm 5$ & $74 \pm 6$ & $8 \pm 2$ & (Korgiopoulos \& Pekguleryuz, 2020) \\
\hline Mg-6Al with trace Y & $235 \pm 13$ & $72 \pm 11$ & $13 \pm 3$ & (Korgiopoulos \& Pekguleryuz, 2020) \\
\hline Mg-6Al-0.3Y & $209 \pm 17$ & $86 \pm 10$ & $9 \pm 2$ & Current work \\
\hline
\end{tabular}

Table 4. Compression properties of as cast samples at room temperature

\begin{tabular}{lcccl}
\hline Alloy & CS(MPa) & CYS(MPa) & Strain(\%) & Reference \\
\hline Mg-6Al & $276 \pm 8$ & $105 \pm 8$ & $23 \pm 1$ & (Korgiopoulos \& Pekguleryuz, 2020) \\
\hline Mg-6Al with trace Y & $271 \pm 3$ & $97 \pm 5$ & $28 \pm 2$ & (Korgiopoulos \& Pekguleryuz, 2020) \\
\hline Mg-6Al-0.3Y & $258 \pm 6$ & $69 \pm 6$ & $28 \pm 2$ & Current work \\
\hline
\end{tabular}

\section{Conclusions}

The addition of $0.3 \mathrm{wt} \% \mathrm{Y}$ improves the tensile properties and the strain to fracture in compression of the binary cast alloys Mg-6wt\%Al. The improvement in ductility and UTS is not as significant as lower (trace level) $\mathrm{Y}$ additions. $\mathrm{Al}_{2} \mathrm{Y}$ precipitates (determined via $\mathrm{XRD}$ and $\mathrm{SEM} / \mathrm{EDS}$ ) are in close association with the $\mathrm{Mg}_{17} \mathrm{Al}_{12}$ phase indicating their role as nucleants but the early formation of the $\mathrm{Al}_{2} \mathrm{Y}$ in the liquid in $\mathrm{Mg}-\mathrm{Al}-0.3 \mathrm{Y}$ leads to its coarsening, resulting in some loss in mechanical properties compared to the alloy with the trace level of $Y$. 
Table 5. Equilibrium and non-equilibrium (Scheil) thermodynamic calculations

\begin{tabular}{|c|c|c|c|c|c|}
\hline Alloy(wt\%) & $\begin{array}{l}\text { Equilibrium - } \\
\text { Y solubility in } \\
\alpha-\mathrm{Mg}(\text { wt } \%)\end{array}$ & $\begin{array}{l}\text { Scheil - Y solubility } \\
\text { in } \alpha-M g(w t \%)\end{array}$ & Y enriched phases & $\begin{array}{l}\text { Scheil- } \\
\text { Formation } \\
\text { temperature } \\
\text { of } \mathrm{Mg}_{17} \mathrm{Al}_{12}\end{array}$ & $\begin{array}{c}\text { Scheil-Formation } \\
\text { temperature of } Y \\
\text { enriched } \\
\text { precipitates }\end{array}$ \\
\hline $\mathrm{Mg}-0.01 \mathrm{Y}$ & 0.01 & 0.01 & $\mathrm{Y}_{10} \mathrm{Mg}_{24} \mathrm{Mg}_{24}$ & - & - \\
\hline$M g-0.3 Y$ & 0.03 & 0.29 & $\mathrm{Y}_{10} \mathrm{Mg}_{24} \mathrm{Mg}_{24}$ & - & - \\
\hline Mg-6Al-0.01Y & $5.51 \mathrm{E}-21$ & 0.00007 & $\mathrm{Al}_{4} \mathrm{MgY}$ & $439^{\circ} \mathrm{C}$ & $460^{\circ} \mathrm{C}$ \\
\hline Mg-6Al-0.3Y & $5.51 \mathrm{E}-21$ & 0.0027 & $\begin{array}{c}\mathrm{Al}_{2} \mathrm{Y} / \mathrm{Al}_{3} \mathrm{Y} \text { (Scheil), } \\
\mathrm{Al}_{4} \mathrm{MgY}\end{array}$ & $439^{\circ} \mathrm{C}$ & $\begin{array}{l}555^{\circ} \mathrm{C}\left(\mathrm{Al}_{3} \mathrm{Y}\right), \\
610^{\circ} \mathrm{C}\left(\mathrm{Al}_{2} \mathrm{Y}\right), \\
510^{\circ} \mathrm{C}\left(\mathrm{Al}_{4} \mathrm{MgY}\right)\end{array}$ \\
\hline
\end{tabular}

Funding Information and acknowledgements. This work was supported by the Natural Sciences and Engineering Research Council of Canada (NSERC) Discovery Grant (G210358NSERCRGPIN-2016-05121). The authors thank Pierre Vermette and Dr. Amir Farkoosh for their assistance in alloy casting and discussions. Konstantinos Korgiopoulos gratefully acknowledges McGill Engineering Doctoral Award program (MEDA).

Author contributions. K. Korgiopoulos and M. Pekguleryuz conceived and designed the study. K. Korgiopoulos conducted data gathering, their analysis and interpretation. Both authors wrote the article.

Data availability statement. The raw/processed data cannot be shared at this time as the data also forms part of an ongoing study.

Conflict of interest. The authors declare that they have no known competing financial interests or personal relationships that could have appeared to influence the work reported in this article.

\section{References}

Bale, C. W., Chartrand, P., Degterov, S. A., Eriksson, G., Hack, K., Mahfoud, R. B., \& Petersen, S. (2002). FactSage thermochemical software and databases. Calphad, 26, 189-228.

Boby, A., Pillai, U. T. S., \& Pai, B. C. (2013). Investigation on lead and yttrium addition on the microstructure and mechanical properties of AZ91 magnesium alloy. Journal of Solid Mechanics and Materials Engineering, 7, 273-280.

Cai, H., Guo, F., Su, J., Liu, L., \& Chen, B. (2018). Study on microstructure and strengthening mechanism of AZ91-Y magnesium alloy. Materials Research Express, 5, 36501. doi: https://doi.org/10.1088/2053-1591/aab0b7.

Chang, H.-W., Qiu, D., Taylor, J. A., Easton, M. A., \& Zhang, M.-X. (2013). The role of Al2Y in grain refinement in Mg-Al-Y alloy system. Journal of Magnesium and Alloys, 1, 115-121.

Friedrich, H. E., \& Mordike, B. L. (2006). Magnesium technology (Vol. 788). Springer.

Gao, P., Hensley, R., \& Zielke, A. (2014). A road map to the future for the auto industry. McKinsey Quarterly, Oct, 1-11. https:// www.mckinsey.com/ /media/McKinsey/Industries/Automotive and Assembly/Our Insights/A road map to the future for the auto industry/A road map to the future for the auto industry.pdf.

Kashefi, N., \& Mahmudi, R. (2012). The microstructure and impression creep behavior of cast AZ80 magnesium alloy with yttrium additions. Materials \& Design, 39, 200-210. doi: https://doi.org/10.1016/j.matdes.2012.02.036.

Kawamura, Y., \& Yamasaki, M. (2007). Formation and mechanical properties of Mg97Zn1RE2 alloys with long-period stacking ordered structure. Materials Transactions, 48, 2986-2992.

Korgiopoulos, K., \& Pekguleryuz, M. (2020). The significant effect of trace yttrium level on the mechanical properties of cast $\mathrm{Mg}-6 \mathrm{Al}$ alloy through a refinement mechanism. Materials Science and Engineering: A, 775, 138966.

Nave, M. D., Dahle, A. K., \& StJohn, D. H. (2000). Eutectic growth morphologies in magnesium-aluminium alloys. Magnesium Technology, 2000, 233-242. doi: https://doi.org/10.1002/9781118808962.ch33.

Pan, F.-S., Chen, M.-B., Wang, J.-F., Jian, P., \& Tang, A.-T. (2008). Effects of yttrium addition on microstructure and mechanical properties of as-extruded AZ31 magnesium alloys. Transactions of Nonferrous Metals Society of China, 18, s1-s6.

Pourbahari, B., Emamy, M., \& Mirzadeh, H. (2017). Synergistic effect of Al and Gd on enhancement of mechanical properties of magnesium alloys. Progress in Natural Science: Materials International, 27, 228-235.

Rasband, W. S. (2011). ImageJ, US National Institutes of Health, Bethesda, Maryland, USA. http://imagej.nih.gov/ij/.

Sandlöbes, S., Friák, M., Zaefferer, S., Dick, A., Yi, S., Letzig, D., \& Raabe, D. (2012). The relation between ductility and stacking fault energies in Mg and Mg-Y alloys. Acta Materialia, 60, 3011-3021. 
Su, G.-H., Zhang, L., Cheng, L.-R., Liu, Y.-B., \& Cao, Z.-Y. (2010). Microstructure and mechanical properties of Mg-6Al-0.3 $\mathrm{Mn}-\mathrm{xY}$ alloys prepared by casting and hot rolling. Transactions of Nonferrous Metals Society of China, 20, 383-389. doi: https://doi.org/10.1016/S1003-6326(09)60150-3.

Tahreen, N., Chen, D. L., Nouri, M., \& Li, D. Y. (2016). Effect of yttrium addition on texture development in a cast Mg-Al-Y magnesium alloy during compression. In M. Alderman, M. V Manuel, N. Hort, \& N. R. Neelameggham (Eds.), Magnesium Technology 2014 (pp. 269-272). Springer, Cham. https://doi.org/10.1007/978-3-319-48231-6_51.

Wang, C., Dai, J., Liu, W., Zhang, L., \& Wu, G. (2015). Effect of Al additions on grain refinement and mechanical properties of $\mathrm{Mg}-\mathrm{Sm}$ alloys. Journal of Alloys and Compounds, 620, 172-179.

Wang, L., Feng, Y., Guo, E., Wang, L., Fu, Y., Zhao, S., \& Cao, G. (2019). Comparative study on microstructure and mechanical properties of $\mathrm{Mg}-3 \mathrm{Nd}-3 \mathrm{Al}$ and $\mathrm{Mg}-3 \mathrm{Nd}-0.5 \mathrm{Zr}$ alloys under different heat treatment conditions. JOM, 71, 2194-2201.

Wang, S.-R., Guo, P.-Q., Yang, L.-Y., \& Wang, Y. (2009). Microstructure and mechanical properties of AZ91 alloys by addition of yttrium. Journal of Materials Engineering and Performance, 18, 137-144. doi: https://doi.org/10.1007/s11665008-9255-Z.

Zou, H., Zeng, X., Zhai, C., \& Ding, W. (2005). The effects of yttrium element on microstructure and mechanical properties of Mg-5 wt.\% Zn-2 wt.\% Al alloy. Materials Science and Engineering: A, 402, 142-148.

Cite this article: Korgiopoulos K, Pekguleryuz M (2021). The effect of $Y$ on the microstructure and mechanical performance of an Mg-Al-Y casting alloy Experimental Results, 2, e7, 1-9. https://doi.org/10.1017/exp.2020.63 


\title{
Peer Reviews
}

\section{Reviewing editor: Dr. Eva Unger}

Lund University, Lund, Sweden, 22100

This article has been accepted because it is deemed to be scientifically sound, has the correct controls, has appropriate methodology and is statistically valid, and has been sent for additional statistical evaluation and met required revisions.

doi:10.1017/exp.2020.63.pr1

\section{Review 1: The effect of $Y$ on the microstructure and mechanical performance of an Mg-Al-Y casting alloy}

\section{Reviewer: Ali Arslan Kaya}

Date of review: 13 November 2020

\begin{abstract}
(c) The Author(s), 2021. Published by Cambridge University Press. This is an Open Access article, distributed under the terms of the Creative Commons Attribution licence (http://creativecommons.org/licenses/by/4.0), which permits unrestricted re-use, distribution and reproduction, provided the original article is properly cited.
\end{abstract}

Conflict of interest statement. Reviewer declares none.

Comments to the Author: This is a useful and detailed work. The only comment which seems unjustified scientifically is the following: "These changes in mechanical properties are not due the well 127 known effect of Y on SFE and LPSO since Y has negligible solubility in the a-Mg according to the thermodynamic calculations and EDS results"

I strongly advise that this comment should be changed. Although the solubility of Y in Mg is low, it is not zero. And even ppm levels of a foreign atom in any host metal can alter the SFE of some crystal planes and directions. Therefore such an effect of "low Y" levels in the system studied cannot be ruled out. And frankly speaking, this study presents no finding to justify the claim made in "Conclusions". There exist many studies showing the effect of Y on SFEs in Mg in literature. In short, this claim is highly misleading and therefore, need be changed.

Thank you.

\section{Score Card}

\section{Presentation}

Does the paper cite relevant and related articles appropriately? (30\%)

\section{Context}


Does the introduction give appropriate context? (25\%)

Is the objective of the experiment clearly defined? (25\%)

Analysis

Does the discussion adequately interpret the results presented? (40\%)

Is the conclusion consistent with the results and discussion? (40\%)

Are the limitations of the experiment as well as the contributions of the experiment clearly outlined? (20\%) 


\section{Review 2: The effect of $Y$ on the microstructure and mechanical performance of an Mg-Al-Y casting alloy}

Reviewer: Dr. V Pavlyuk (i)

Date of review: 15 October 2020

(C) The Author(s), 2021. Published by Cambridge University Press. This is an Open Access article, distributed under the terms of the Creative Commons Attribution licence (http://creativecommons.org/licenses/by/4.0), which permits unrestricted re-use, distribution and reproduction, provided the original article is properly cited.

Conflict of interest statement. Reviewer declares none

Comments to the Author: The information on the mass of prepared alloys and the mass losses during the preparation should be added to the description of the experimental procedure.

The obtained alloys were controlled by means of X-ray diffraction (XRD). What type of radiation was used (FeK, CuK, or other)? Indicate this in the manuscript.

The authors must add the results of XRD Rietveld refinements, please provide more details and explanations about the structure refinements for all observed phases.

Usually, magnesium alloys melt in tantalum crucibles. Explain why graphite crucibles have been chosen?

The EDS data should be reported with the standard deviations for all elements (Table 1).

\section{Score Card}

\section{Presentation}

3.3

Is the article written in clear and proper English? (30\%)

Is the data presented in the most useful manner? (40\%)

Does the paper cite relevant and related articles appropriately? (30\%)

Context

Does the abstract correctly embody the content of the article? (25\%)

Does the introduction give appropriate context? (25\%)

Is the objective of the experiment clearly defined? (25\%)

Analysis

Does the discussion adequately interpret the results presented? (40\%)

Is the conclusion consistent with the results and discussion? (40\%)

Are the limitations of the experiment as well as the contributions of the experiment clearly outlined? (20\%) 